\title{
ASSOCIATION OF G.2686T>C MUTATION OF MBL1 GENE WITH REPRODUCTION TRAITS IN SAHIWAL CATTLE
}

\author{
KAMALDEEP ${ }^{1}$, ANKIT MAGOTRA ${ }^{2}$, B. L. PANDER ${ }^{3}$, ANIKA MALIK ${ }^{4}$, \\ ASHA RANI GARG ${ }^{5}$, D. S. DALAL ${ }^{6} \&$ B. S. MALIK ${ }^{7}$ \\ ${ }^{1}$ Research Scholar Animal Genetics and Breeding, LUVAS, Hisar, Haryana, India \\ ${ }^{2}$ Assistant Professor, Department of Animal Genetics and Breeding, LUVAS, Hisar, Haryana, India \\ ${ }^{3}$ Ex-Professor and Head, Department of Animal Genetics and Breeding, LUVAS, Hisar, Haryana, India \\ ${ }^{4}$ Assistant Professor, Department of Veterinary Extension, LUVAS, Hisar, Haryana, India
}

${ }^{5}$ Research worker, Animal Genomics laboratory, Department of Animal Genetics and Breeding, LUVAS, Hisar, Haryana, India

${ }^{6}$ Professor, Department of Animal Genetics and Breeding, LUVAS, Hisar, Haryana, India

${ }^{7}$ Principal Scientist, Department of Animal Genetics and Breeding, LUVAS, Hisar, Haryana, India

\section{ABSTRACT}

Mannose-binding lectin $(M B L)$ is one of the potent constituent of defense system. MBL gene possibly contributes to bacterial infection resistance and was proposed as a molecular marker for reproductive health. Randomly 24 Sahiwal cows were selected to screen for g.2686T>C point mutation in exon 2 of MBL1 gene and its association with Age at First Calving (AFC) and First Calving Interval (FCI). Targeted genomic sequence encompassing targeted g.2686T>C mutation was amplified and digested with Hae III to genotype reported SNP. Genotype analysis using PCRRFLP revealed a polymorphic banding pattern. The preliminary information obtained from the study indicated that the targeted variant of MBL1 gene in indigenous cattle had no association with Age at first calving (AFC) and first calving interval (FCI). However, TT genotype animals revealed lowest AFC (1208.27 98.35 days) compare to TC (1215 \pm 89.85

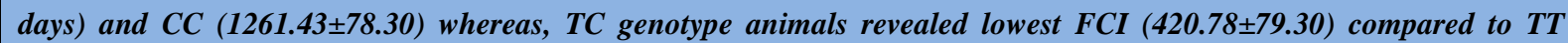

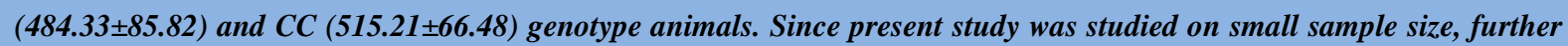
studies with large sample size are required to explore fully the association of g.2686T>C in sahiwal cattle.

KEYWORDS: MBL1, AFC, FCI, Polymorphism \& Sahiwal

Received: Oct 05, 2017; Accepted: Oct 26, 2017; Published: Nov 06, 2017; Paper Id.: IJASRDEC201721

\section{INTRODUCTION}

Reproduction is very important for conservation and propagation for all species. Sexual reproduction processes are quite conserved and well defined, but the underlying molecular and genetic basis is much less known (de Vries, 1989; Rothschild and Bidanel, 1998). In cattle, heritability for nearly all measures of fertility are only 15\% (Cammacketal, 2009), and are negatively genetically correlated with milk production traits. The complexity and transient nature of specific reproductive processes are the cause of reduced knowledge concerning their molecular basis (Matzuk and Lamb, 2008). Therefore, much effort is made to identify the ways for improving these traits. This improvement of reproductive traits is related to different fields, with management, nutrition and genetics having a great impact. Regarding genetic improvement, available work has mainly focused on traditional selection, that is, reproductive animals have been selected using phenotypic information on productive traits, rather than using information on associated genetic markers. Nevertheless, reproductive traits are characterized by low 
herit abilities and a complex genetic basis and are thus, difficult to improve using traditional selection methods. These restrictions, have led to a growing interest in the identification and characterization of specific genes and genomic regions, implicated in the variability and regulation of reproductive pros.

Mannose binding lectin (MBL) potent, constituent of defense system (Nethet al.,2000; Bouwman, 2006), is a member of the collect in the family of proteins, characterized by the presence of collagen-like domains and carbohydrate recognition lectin domains. MBL binds to high mannose and Nacetyl-glucosamine oligosaccharides, permits the protein to interact, with a wide selection of microorganisms coated with such sugars such as yeasts, bacteria and viruses and serves as the initiator of the third pathway of complement system (lectin pathway). MBL is considered to be involved in the innante immunity of host defence that works, prior to the establishment of adaptive immune system. Innate immunity remains imperative, to defend the female reproductive tract from the adverse effects of microbial infections. These infections are very important and area of concern in cattle, where bacteria and viruses commonly cause infertility (Sheldon et.al. 2014). The bovine Mannose-binding lectins (MBL1) gene is located on Chromosome 28 (Gjerstorffet al, 2004). It contains five exons, encoding a 248 a protein. Mannose Binding Lectins (MBL) gene, possibly contributes to bacterial infection resistance and was proposed as a molecular marker for traits associated with disease (Liu et al., 2011) that ultimately effects production and reproduction traits. The MBL1 polymorphism appeared to be a promising indirect marker to improve mastitis resistance in cattle (Yuan et al., 2013). The present study was undertaken with an aim to screen g.2686T $>C$ point mutation in exon 2 of MBL1 gene and its in association with Age at first calving (AFC) and first calving interval (FCI).

\section{MATERIALS AND METHODS}

\section{Animals under Study}

The present study was conducted on 24 Sahiwal cattle, maintained at Cattle Breeding Farm, Lala Lajpat Rai University of Veterinary and Animal Science (LUVAS), Hisar, India. $5 \mathrm{ml}$ blood was collected aseptically by jugular vein puncture in a sterile EDTA vacationer. The samples were transported to the Animal Genomics Laboratory, Animal Genetics and Breeding Department, LUVAS, Hisar in an icebox, for further processing. Genomic DNA was extracted from blood, by Phenol Chloroform method (Sambrook and Russsel,1989). Quality and quantity of the isolated genomic DNA was evaluated, using UV-vis spectrophotometer.

\section{PCR Amplification}

Reported set of oligo nucleotide primers (Wang et al., 2011) were used, to amplify targeted genomic region of MBL1 gene to genotype g.2686T $>C$ point mutation in Sahiwal cattle. The primer sequence, target region and amplicon size are given in Table I. PCR amplification was carried out in a total volume of 25 ul, with $100 \mathrm{ng}$ DNA template, $2 \mathrm{X}$ PCR master mix (Fermantas), 10 pmol of each primer. PCR was carried out in thermal cycler (T-100 Bio Rad), in following stages - initial denaturation at $94{ }^{\circ} \mathrm{C}$ for $5 \mathrm{~min}$., followed by 35 cycles of $94{ }^{\circ} \mathrm{C}$ for 30 s, annealing at $59{ }^{\circ} \mathrm{C}$ for 30 $\mathrm{s}, 72{ }^{\circ} \mathrm{C}$ for $30 \mathrm{~s}$ and a final extension at $72{ }^{\circ} \mathrm{C}$ for $5 \mathrm{~min}$. The PCR products were separated on $1.5 \%$ agarose gels, including $0.5 \mu \mathrm{g} / \mathrm{ml}$ of ethidium bromide, and then photographed in Geldoc and photographs were taken.

\section{PCR - RFLP}

In the present study, candidate SNP viz., g.2686T>C in exon 2 of MBL1 gene was targeted and genotyped, by PCR-RFLP in Sahiwal cattle. Amplified PCR products (10 $\mu$ l) were digested with $2 \mathrm{U}$ Hae III restriction enzyme, at 37 
${ }^{\circ} \mathrm{Cfor} 12 \mathrm{~h}$. The digested product was separated on $2.5 \%$ agarose gel and the gel was stained with ethidium bromide.

\section{Statistical Analysis}

Association of genotypes, season of calving and period of calving with AFC and FCI was analyzed using least squares method, of the General Linear Model Procedure. The data were classified, according to season of calving, period of birth. The months were grouped into four seasons based on climatic conditions i, e winter (December to March), summer (April to June), Rainy (July to September), autumn (October to November). The expression of different traits varied in different periods due to change in managerial practices over the time. Year to year variations were expected to be small and hence, the years were grouped into two periods. i.e. Period 1:2004-2008, Period 2: 2009-2012.

Following model was used:

$$
Y_{i j k l}=\mu+G_{i}+P_{j}+S_{k}+e_{i j k l}
$$

Where,

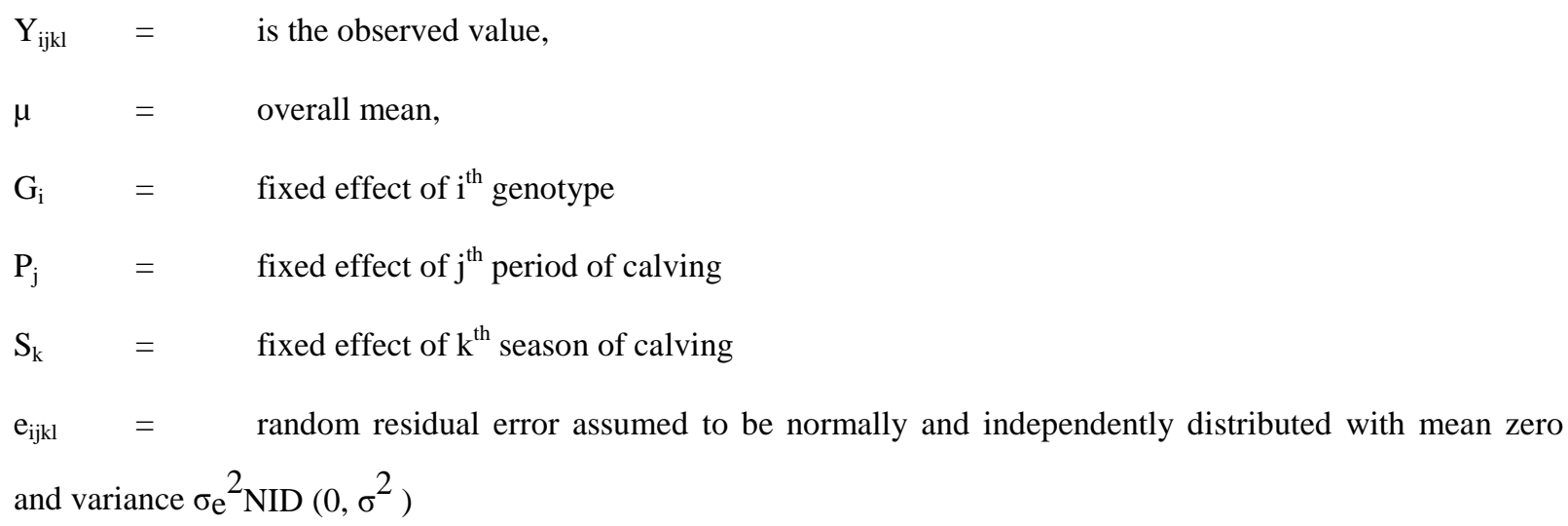

\section{RESULTS AND DISCUSSIONS}

Understanding the genetic architecture of female reproductive system would offer the opportunity to exploit natural variation and improvement of reproductive traits by selective breeding programs through marker assisted selection. Molecular genetics and genomics are the field of biology that studies the structure and function of genes and genomes at a molecular (nucleic acids) level (Matzuk and Lamb, 2008).

There are a number of candidate genes like major histocompatibility complexes (MHC), interleukins (IL), toll like receptors (TLR), lactoferrin, CARD15, FEZL, CD14, complement component 4 (C4A), Mannose Binding Lectins (MBL1 and MBL2) etc., which are associated with resistance against mastitis. Among these, C4A, MBL1 and MBL2 are excellent immunity related candidate genes (Rupp and Boichard, 2003; Wang et al., 2012; Zhao et al., 2012).

Mannose-binding lectin (MBL) is one of the most important constituent and is a pattern recognition molecule of the innate immune system (Nethet al., 2000; Bouwman, 2006). It binds to a range of sugars, including N-acetyl-D glucosamine, mannose, $\mathrm{N}$-acetyl-mannosamine, fructose and glucose. This permits the protein, to interact with a wide selection of microorganisms coated with such sugars. Mannose binding lectin, bound to microbial surfaces is able to activate the complement system, in an antibody and $\mathrm{C} 1$-independent manner. There are other very serious complications, associated with therapeutic interventions that lead to antibiotic resistance, effectiveness and animal welfare issues. 
This study provides preliminary information regarding association of genetic variants of MBL1 gene with AFC and FCI in Sahiwal cattle. In this study SNP g.2686T>Cin exon 2 of MBL 1 gene was targeted and genotyped by PCR RFLP. The PCR product of 401 bp size encompassing g.2686T >C mutation in exon 2 of MBL1, was digested with the Hae III restriction enzyme. All the three possible genotypes were i.e. TT (274, 127 bp), TC (274, 184, 127 and 90 bp), and CC (184, 127 and 90 bp) was observed inour studied population (Fig. 1 and 2). Wang et al. (2011) also reported all three genetic variants of this SNP in Chinese Holstein, Luxi Yellow and Bohai Black cattle breeds.

\section{Allele and Genotypic Frequency}

The genotype and allele frequencies of the observed SNP were presented in Table 3. The frequency of allele C (0.60) was found dominant as compared to allele $\mathrm{T}(0.40)$ in our studied cattle population. Chi-square $\left(\chi^{2}\right)$ analysis revealed that the population of under study is in Hardy Weinberg equilibrium.

\section{Association of Genotypes, Season of Calving and Period of Calving with AFC and FCI}

In the present study, the AFC and FCI was not associated with genotypes as well as with season and period of

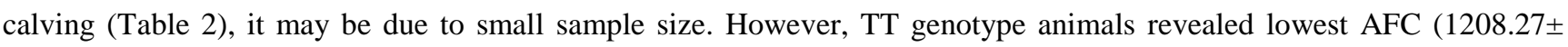
98.35 days) compare to TC (1215 \pm 89.85 days) and CC (1261.43 \pm 78.30$)$ genotype whereas, TC genotype animals revealed

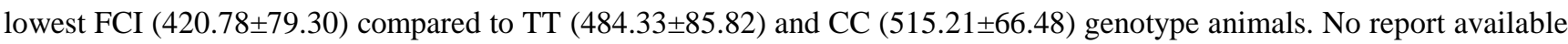
regarding association of $2686 \mathrm{~T}>\mathrm{C}$ mutation with reproduction traits in cattle. We attempted first time association of reproductive traits of cattle with targeted SNP of MBL 1 gene in Sahiwal cattle.

\section{CONCLUSIONS}

The present study was carried out on Sahiwal cattle, with the aim to identify marker associated with reproduction trait i.e AFC and FCI. We genotyped reported SNP g.2686T>C in our resource population, by PCR-RFLP. All the three genotypes i.e TT, TC and CC were revealed in our targeted population. The frequency of allele C (0.60) was found dominant as compared to allele T (0.40) in our studied Sahiwal cattle population. AFC and FCI was not associated with genotypes as well as with season and period of calving, it may be due to small sample size. However, TT genotype animals revealed lowest AFC and TC genotype animals revealed lowest FCI, as the present study was conducted on relatively small sample size. Further studies need to be warranted on large sample size.

Table 1: Sequence of the Primers

\begin{tabular}{|c|c|c|c|c|c|}
\hline SNP & Primer Sequence & $\begin{array}{c}\text { AT } \\
\left.{ }^{\circ} \mathbf{C}\right)\end{array}$ & SAF (bp) & RE & RES, bp/genotype \\
\hline Primer I & $\begin{array}{c}\text { 5' GCAGAGGTGGTGGCAAATGT 3' } \\
\text { 5' CATCTTTAGAGAGAATGCCCC 3, }\end{array}$ & $59^{\circ} \mathrm{C}$ & 401 & HAE III & $\begin{array}{c}\text { TT- }-274,127 \\
\text { CC- } 184,127,90\end{array}$ \\
\hline
\end{tabular}

AT-Annealing temperature, SAF- specific amplified fragment, RE- Restriction enzyme, RES- Restriction enzyme site

Table 2: Effect of Genotype (g.2686T >C), Period of Calving and Season of Calving on AFC \& FCI in Sahiwal

\begin{tabular}{|l|c|c|}
\hline & AFC & FCI \\
\hline N & 24 & 20 \\
\hline Genotype & & \\
\hline TT & $1208.27 \pm 98.35$ & $484.33 \pm 85.82$ \\
\hline
\end{tabular}




\begin{tabular}{|l|c|c|}
\hline \multicolumn{3}{|c|}{ Table 2: Contd., } \\
\hline TC & $1215.21 \pm 89.85$ & $420.78 \pm 79.30$ \\
\hline CC & $1261.43 \pm 78.30$ & $515.21 \pm 66.48$ \\
\hline Season & & \\
\hline Winter & $1152.79 \pm 95.67$ & $519.30 \pm 77.96$ \\
\hline Summer & $1331.70 \pm 92.00$ & $474.31 \pm 80.36$ \\
\hline Rainy & $1248.14 \pm 98.61$ & $493.67 \pm 85.99$ \\
\hline Autumn & $1180.57 \pm 72.56$ & $406.48 \pm 59.10$ \\
\hline Period & & \\
\hline Period 1 & $1201.61 \pm 155.03$ & $428.19 \pm 13$ \\
\hline Period 2 & $1254.99 \pm 33.86$ & $518.69 \pm 30.66$ \\
\hline
\end{tabular}

Table3: Genotype and Allele Frequency of g.2686T $>C$ Mutation of MBL1 Gene in Sahiwal

\begin{tabular}{|c|c|c|c|c|c|c|c|}
\hline \multirow{2}{*}{ Breeds } & \multicolumn{2}{|c|}{ Genotype Frequency } & Total & \multicolumn{2}{c|}{ Allele Frequency } & Hardy Weinberg \\
\cline { 2 - 6 } & CC & CT & TT & & C & T & Equilibrium $\chi^{2}$ Test \\
\hline Sahiwal & $9(0.37)$ & $11(0.46)$ & $4(0.17)$ & 24 & 0.60 & 0.40 & $0.289^{\text {ns }}$ \\
\hline
\end{tabular}

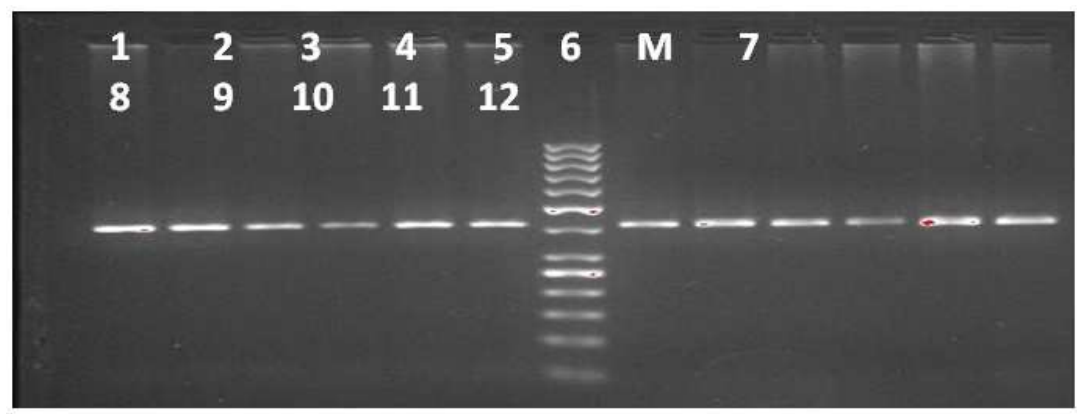

Figure 1: Resolution of PCR Products (exon 2) in MBL1 Gene

Lane 1- 12: PCR Product (401 bp)

Lane M: 50 bp DNA ladder

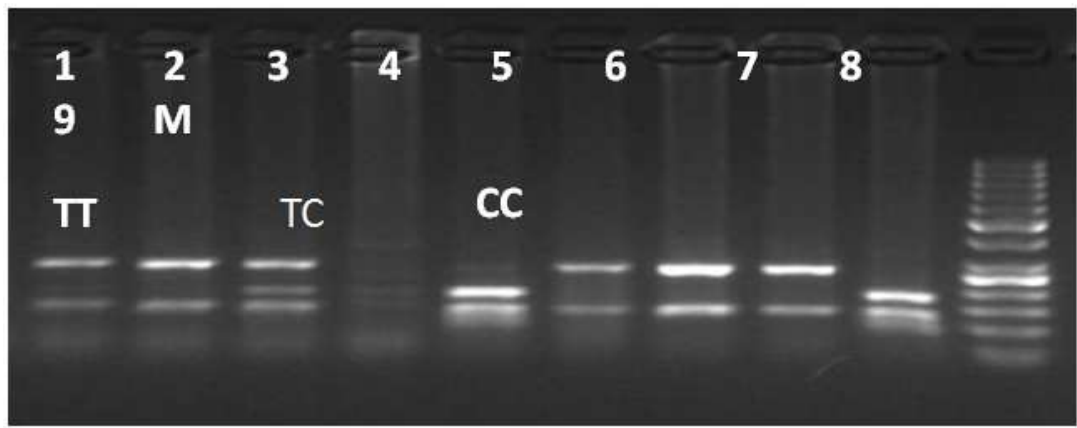

Figure 2: PCR-RFLP (g.2686T>C) MBL1 Genotyping in Sahiwal Cattle

TT Genotype - 274, 127 bp

TC Genotype - 274, 184, 127, 90 bp

CC Genotype - 184, 127, 90 bp

M - 50 bp Marker 


\section{REFERENCES}

1. Bouwman, L.H., Roep, B.O. and Roos, A. (2006) Mannose-binding lectin: clinical implications for infection, transplantation, and autoimmunity. Hum Immunol67:247-256.

2. Cammack K.M., Thomas M.G., Enns R.M. (2009) Reproductive Traits and their Heritabilities in Beef Cattle.The Professional Animal Scientist 25: 517-528.

3. deVries A. G. (1989). A model to estimate economic value of traits in pig breeding.Livestock Production Science 21: 49-66.

4. Gjerstorff, M., Hansen, S., Jensen, B., Dueholm, B., Horn, P., Bendixen, C. and Holmskov, U. (2004). The genes encoding bovine SP-A, SP-D, MBL-A, conglutinin, CL-43 and CL-46 form a distinct collectin locus on Bos taurus chromosome 28 (BTA28) at position q.1.8-1.9. Anim. Genet. 35, 333-337.

5. Liu, J., Ju, Z., Li, Q., Huang, J., Li, R., Li, J., Ma, L., Zhong, J. and Wang, C. (2011). Mannose-binding lectin 1 haplotypes influence serum MBL-A concentration, complement activity, and milk production traits in Chinese Holstein cattle. Immunogenetics.63: 727-742.

6. Neth, O., Jack, D.L., Dodds, A.W., Holzel, H., Klein, N.J. and Turner, M.W. (2000). Mannose-binding lectin binds to a range of clinically relevant microorganisms and promotes complement deposition. Infect Immun 68:688-693.

7. Matzuk, M.M. and Lamb, D.J.(2008). The biology of infertility: research advances and clinical challenges. Nature Medicine 14: 1197-1213.

8. Rothschild M.F., and Bidanel J.P. (1998). Biology and Genetics of Reproduction. 313-343 in TheGenetics of the Pig. M. F. Rothschild and A. Ruvinsky, ed. CAB Int., Univ. Press, Cambridge, U.K.

9. Rupp, R. and Boichard, D. (2003).Genetics of resistance to mastitis in dairy cattle.Vet. Res. 34: 671-688.

10. Sambrook, J. and Russell, D. W. (1989). Preparation and analysis of eukaryotic DNA. In: Molecular Cloning: A Laboratory Manual. $3^{\text {rd }}$ Edition. Cold Spring Harbor Laboratory Press, New York: 6.1-6.62.

11. Deepak Kumar et al., Age Wise Comparison of Hematological, Biochemical and Hormonal Parameters of Sahiwal, International Journal of Agricultural Science and Research (IJASR), Volume 7, Issue 2, March - April 2017, pp. 171-176

12. Sheldon,I.M., Cronin, J.G., Healey, G. D.,Gabler,G.,Heuwieser,W., Streyl, D., Bromfield, J.J., Miyamoto, A., Fergani, C. and Dobson,H.(2014).Innate immunity and inflammation of the bovine femalereproductive tract in health and disease.Reproduction148: R41-R51.

13. Wang, C.F., Liu, M., Li, Q.L., Ju, Z.H., Huang, J.M., Li, J.B. and Zhong, J.F. ( 2011).Three novel single-nucleotide polymorphims of MBL1 gene in Chinese native cattle and their associations with milk performance traits. Vet. Immunol.Immunopathol.139, 229-236.

14. Wang, X., Ju, Z., Huang, J., Hou, M., Zhou, L., Qi, C., zhang. Y., Gao. Q., Pan. Q., Li.G.,Zhong, J. and Wang, C. (2012). The relationship between the variants of the bovine MBL2 gene and milk production traits, mastitis, serum MBL-C levels and complement activity. Veterinary Immunologyand Immunopathology.148, 311- 319

15. Yuan, Z., Li, J., Li, J., Gao, X. and Xu, S. (2013). SNPs identification and its correlation analysis with milk somatic cell score in bovine MBL1 gene. Mol. Biol. Rep.,40(1): 7-12.

16. Zhao, Z.L., Wang, C.F., Li, Q.L., Ju, Z.H., Huang, J.M., Li, J.B., Zhong, J.F. and Zhang, J.B. (2012).Novel SNPs of the mannan-binding lectin 2 gene and their association with production traits in Chinese Holsteins.Genet.Mol. Res. 11 (4): $3744-$ 3754. 